\title{
Application of Autologous Blood Cell Salvage in Off-Pump Coronary Artery Bypass Graft Operation
}

\author{
Hui Zhao, ${ }^{1}$ Huimin $\mathrm{Ma},{ }^{2}$ Li Meng, ${ }^{3}$ Ziniu Zhao, ${ }^{1}$ Xiaoqiang Quan, ${ }^{1}$ Zhaoyun Cheng ${ }^{1}$ \\ Department of ${ }^{1}$ Cardiac Surgery and ${ }^{2}$ Special Service Center, Henan Province People's Hospital; ${ }^{3}$ Department of Cardiac \\ Surgery, Zhengzhou People's Hospital (Henan Province Chest Hospital), Zhengzhou, China
}

\section{ABSTRACT}

Objective: To analyze whether application of autologous blood cell salvage can reduce the transfusion volume of allogeneic blood and complications of blood transfusion in offpump coronary artery bypass operations.

Methods: We randomly divided 120 patients into autologous blood cell salvage group (experimental group, $\mathrm{n}=60$ ) and non-autologous blood cell salvage group (control group, $n=60$ ). Volume of perioperative allogeneic blood transfusion of each patient was recorded. Moreover, complications and ICU retention times $(\mathrm{H})$ of each patient were also recorded. The data were analyzed using $t$ tests.

Results: The volume of allogeneic blood transfusion was significantly less in the experimental group than in the control group.

Conclusion: Application of autologous blood cell salvage in off-pump coronary artery bypass graft operation can reduce the volume of allogeneic blood transfusion, alleviate blood shortage, and reduce the incidence of postoperative complications, leading to medical, economic, and social benefits.

\section{INTRODUCTION}

In recent years, the focus on blood protection has gradually increased. The use of blood cell salvage as a blood protection procedure is very important, and at present, it is widely used clinically. The procedure involves recycling blood lost after filtration or re-infusing lost blood into the patient. The feasibility and superiority of blood cell salvage has been proven by domestic and foreign research [Jiang 2014; Milne 2015; Vonk 2013].

Improvements in technology have enabled salvaging even very low blood volumes for transfusion into patients. Moreover, with advanced operation skills, bleeding volume of off-pump coronary artery bypass graft surgery is not large. Therefore, this raises the question whether the use of a blood salvage machine for autologous blood cell salvage can reduce allogeneic blood transfusion in patients. In recent

Received May 22, 2016; received in revised form fanuary 21, 2017; accepted February 2, 2017.

Correspondence: Zhaoyun Cheng, Department of Cardiac Surgery, Henan Province People's Hospital, No. 7 Weiwu Road, Zhengzhou 450003, China; +86 13903712068; fax:+8637165580860 (e-mail: zhaoyunchencn@126.com). years, differing opinions on the application of autologous blood cell salvage in off-pump coronary artery bypass operation have been reported. Studies have shown that off-pump coronary artery bypass operation using blood cell salvage can reduce the risks of postoperative blood transfusion in patients [Kuss 2010]. In contrast, Tan et al considered the application of blood cell salvage in off-pump coronary artery bypass graft operation to be unnecessary [Tan 2012]. In this study, we assessed whether the application of blood cell salvage in off-pump coronary artery bypass graft operation can reduce allogeneic blood transfusion and transfusion complications. In addition, we evaluated the economic and social benefits of both procedures.

\section{MATERIALS AND METHODS}

\section{General Data}

One hundred and twenty patients with coronary heart disease between August 2012 and January 2013 were randomly recruited to the study. We included patients aged $40-75$ years, weighing $50-90 \mathrm{~kg}$, undergoing heart coronary bypass graft operation for the first time, without clinical evidence of brain, liver, lung, renal parenchymal, and heart valve diseases, with an ejection fraction of left ventricle $>35 \%$ and lesions on all 3 coronary arteries, for whom grafts were the left internal mammary artery and saphenous vein, and the graft number was 3 to 6 . The exclusion criteria were preoperative anemia and blood coagulation dysfunction conversion to extracorporeal circulation bypass procedure. Ultimately, 120 patients were randomly divided into either the experimental group $(n=60)$ or control group $(n=60)$. Blood cell salvage was performed for all patients in the experimental group. In addition, the volumes of salvaged autologous blood and washed red blood cells were recorded for each patient. Blood cell salvage was not performed in the control group, and a hemoglobin level less than $8 \mathrm{~g} / \mathrm{dL}$ was considered the standard for all patients. This study was conducted in accordance with the Declaration of Helsinki. This study was conducted with approval from the Ethics Committee of Henan Province People's Hospital. Written informed consent was obtained from all participants.

\section{Anesthesia Methods}

All patients were selected for general anesthesia combined with controlled hypotensive anesthesia. An oxygen mask was used for each patient and electrocardiogram and pulse oxygen saturation $\left(\mathrm{SpO}_{2}\right)$ were monitored. Patients' blood 
Table 1. General Data of the Experimental and Control Groups

\begin{tabular}{lccc}
\hline & $\begin{array}{c}\text { Experimental Group } \\
(\mathrm{n}=60)\end{array}$ & $\begin{array}{c}\text { Control Group } \\
(\mathrm{n}=60)\end{array}$ & $P$ \\
& $39 / 21$ & $37 / 23$ & .64 \\
Sex, male/female & $60.48 \pm 9.22$ & $59.26 \pm 7.45$ & .43 \\
Age, y & $68.43 \pm 8.26$ & $68.63 \pm 10.35$ & .91 \\
Weight, kg & $13.04 \pm 1.42$ & $12.98 \pm 1.30$ & .79 \\
Preoperation Hb, g/L & $3.90 \pm 0.97$ & $3.95 \pm 0.93$ & .77 \\
Number of grafting vessels & & &
\end{tabular}

pressures were measured and they also underwent radial artery puncture, and deep vein puncture under local anesthesia, with midazolam, etomidate, fentanyl, and rocuronium used for induction. The method also involved connecting the respirator after intubation, maintaining the partial pressure of carbon dioxide $\left(\mathrm{PaCO}_{2}\right)$ at $35-45 \mathrm{mmHg}$, intraoperative intravenous infusion with remifentanil and propofol, continuous or discontinuous isoflurane inhalation, additional periodical administration of vecuronium, maintaining adequate depth of anesthesia, deepened anesthesia, during cutting, and sawing the sternum. After separating the internal mammary artery, $1-1.5 \mathrm{mg} / \mathrm{kg}$ heparin was administered, maintaining ACT over $280 \mathrm{~s}$. Intraoperative monitoring included invasive blood pressure, central venous pressure, heart rate, hematocrit (HCT), $\mathrm{SpO}_{2}$, end tidal carbon dioxide partial pressure $\left(\mathrm{PetCO}_{2}\right)$, blood gas analysis, temperature, and electrocardiograph. Based on hemodynamic monitoring and observations during surgery, dosage of vasoactive drugs was adjusted to maintain a stable blood pressure and heart rate. After vascular anastomosis, heparin was neutralized with protamine. After surgery, a tracheal tube was placed and the patients were transferred to the ICU with ventilator support.

\section{Blood Cell Salvage}

Blood cell salvage was performed using the Dideco Electa blood cell separator (Sorin Group, Italy) and a disposable kit. A $50 \mathrm{~mL}$ centrifugal cup package was chosen. As an anticoagulant fluid, a solution of $200 \mathrm{mg}$ heparin in $500 \mathrm{~mL} 0.9 \%$ sodium chloride was used. The entire recovery pipeline system was prefilled with $50 \mathrm{~mL}$ anticoagulant fluid and then the blood loss was salvaged through the pipeline from the skin incision with a ratio of 5:1 at a negative pressure of about $150 \mathrm{mmHg}$, while washing with $600-1000 \mathrm{~mL}$ physiological saline each time.

\section{Autologous Blood Transfusion}

The patients were first infused with lactated Ringer's solution, Voluven, or succinylated gelatin through the peripheral or central venous routes, in order to maintain hemodynamic stability as much as possible. After the completion of the main operational steps, the salvaged washed red blood cells were transfused back into the patients. If the bleeding volume became larger, the red blood cells could still be washed and transfused back into the patient. During
Table 2. Comparison of Perioperative Clinical Data between the Two Groups

\begin{tabular}{lccc}
\hline & $\begin{array}{c}\text { Experimental } \\
\text { Group }\end{array}$ & Control Group & $P$ \\
\hline $\begin{array}{l}\text { Allogeneic red blood cell } \\
\text { transfusion, } \mathrm{u}\end{array}$ & $2.47 \pm 0.79$ & $4.07 \pm 0.97$ & 0.00 \\
$\begin{array}{l}\text { Allogeneic blood plasma } \\
\text { transfusion, mL }\end{array}$ & $262.50 \pm 85.68$ & $294.17 \pm 86.89$ & 0.047 \\
$\begin{array}{l}\text { ICU retention time, } \mathrm{h} \\
\text { Complications, } \mathrm{n}(\%)\end{array}$ & $36.98 \pm 12.73$ & $41.92 \pm 10.84$ & 0.024 \\
$\begin{array}{l}\text { Endotracheal intubation } \\
\text { time, h }\end{array}$ & $7(11.7)$ & $19(31.7)$ & 0.048 \\
$\begin{array}{l}\text { Postoperative hospital stay, d } \\
\text { Average hospitalization cost, }\end{array}$ & $10.23 \pm 3.82$ & $25.77 \pm 19.43$ & 0.092 \\
RMB, yuan & 110728.15 & $1348 \pm 4.71$ & 0.13 \\
& & & 0.017 \\
& & &
\end{tabular}

and after transfusion, the patient's vital signs were closely observed; all adverse reactions, such as hemoglobin urine, allergic reactions, and coagulation abnormalities, were recorded. Moreover, autologous blood transfusion volume (namely concentrated red blood cells after washed) and allogeneic blood transfusion volume were also recorded. One day after the operation, routine blood tests and biochemistry were performed; ICU retention time and complications were recorded.

\section{Statistical Analysis}

Data were analyzed by using SPSS 13.0 statistical software. The obtained data were represented as S. Comparison between groups were carried out using independent-sample $t$ tests. $P<.05$ was considered significant.

\section{RESULTS}

General conditions of the 2 groups are shown in Table 1. With respect to sex, age, weight, preoperative hemoglobin, and the number of grafts, no significant differences were found.

The mean salvaged washed red blood cell volume in the experimental group was $261.02 \mathrm{~mL}$, and HCT of the washed red blood cells was $0.42-0.53$, equivalent to $1.5 \mathrm{U}$ suspended red blood cells.

The mean allogeneic red cell transfusion volume and plasma volume in the experimental group was 2.46 units and $266.66 \mathrm{~mL}$, respectively. These results are significantly different from those of the control group, in which the mean allogeneic red cell transfusion volume and plasma volume was 4.30 units and $401.66 \mathrm{~mL}$, respectively $(P<.01)$. The incidence of complications in the experimental group was lower than in the control group. In addition, time in ICU in the experimental group was shorter than in the control group. Both differences were statistically significant (Table 2). 


\section{DISCUSSION}

Allogeneic blood transfusion is associated with several complications and hence has received great attention from the medical community [Ong 2016; Vassal 2016]. Allogeneic blood transfusion has proven to be associated with infectious diseases, adverse reactions, and transfusion complications, which are fatal and costly [Adegoke 2011; Andreasen 2011]. Conversely, it has been suggested that autologous blood transfusion has greater effect in clinical application, and that appropriate, timely, and correct use of autologous blood transfusion technology can ensure hemodynamic stability in the perioperative period in patients with massive hemorrhage. Moreover, the use of autologous blood transfusion technology may prevent mortality at first use of the treatment, or improve opportunities for further treatment, which can reduce blood shortages, prevent the spread of diseases, reduce patient and hospital costs, improve the success rate of rescue, ensure operation efficiency, and provide positive social and economic benefits [Cholette 2013; Scott 2016].

Studies have confirmed that coronary artery bypass grafting-related bleeding greater than $4 \mathrm{U}$ should be considered an independent risk factor for mortality [Stone 2012]. Some authors suggested that blood cell salvage should be made a conventional measure to improve safety of off-pump coronary artery bypass surgery [Saha 2011]. The application of autologous blood transfusion in off-pump coronary artery bypass grafting has clinical value.

We have over 500 cases of off-pump coronary artery bypass graft operations per year in our hospital. We used the Dideco Electa blood collection blood cell separator, with a $50 \mathrm{~mL}$ centrifugal cup package, which allows for even a small amount of bleeding to be measured accurately and washed efficiently. The results showed that the mean salvaged washed red blood cells of the experimental group was $261.02 \mathrm{~mL}$, and the HCT of the washed red cells was from 0.42 to 0.53 .

The mean allogeneic red cell transfusion volume and plasma volume of the experimental group was 2.46 units and $266.66 \mathrm{~mL}$, respectively. These results are significantly different from those of the control group, in which the mean allogeneic red cell transfusion volume and plasma volume was 4.30 units and $401.66 \mathrm{~mL}$, respectively $(P<.01)$. These findings suggest that the application of the intraoperative blood cell salvage machine in off-pump coronary artery bypass operation for autologous blood cell salvage, separation, and transfusion, can reduce the use of allogeneic blood in patients, and alleviate blood shortages. Moreover, complications following operation in the experimental group were significantly lower than that in the control group, which indicates that reduction of allogeneic blood transfusion can reduce postoperative complications.

With respect to costs, the per unit transfusion volume of salvaged autologous blood has a higher price than that of the corresponding allogeneic blood transfusion volume. Therefore, it will cost the patients more to undertake autologous blood cell salvage; however, patients will experience fewer complications, which will reduce intensive care unit retention time, and lead to a smaller overall cost.
Autologous blood transfusion results in the following: prevention of disease spread, reduced patient costs, reduced hospital costs, reduced blood shortage difficulties, improvement in the success rate of rescue, greater social benefits, and efficient surgery, which results in reduction of many complications associated with blood loss.

The blood cell salvage machine has been applied in the off-pump coronary artery bypass operation, in order to salvage, separate, and transfuse autologous blood. The use of this procedure can reduce allogeneic blood transfusion and postoperative complications, alleviate blood shortages, and prevent patient death due to limited blood supply. The limitations of this study were the small sample size and the absence of a postoperative long-term follow-up, both of which should be addressed in future investigations.

\section{Conclusion}

The blood cell salvage machine was applied in off-pump coronary artery bypass operation to salvage, separate, and transfuse autologous blood. The use of this procedure should be favored because it can reduce allogeneic blood transfusion and transfusion complications, leading to medical, economic, and social benefits.

\section{REFERENCES}

Adegoke AO, Akanni O, Dirisu J. 2011. Risk of transfusion-transmitted syphilis in a tertiary hospital in Nigeria. N Am J Med Sci 3:78-81.

Andreasen JJ, Dethlefsen C, Modrau IS, et al. 2011. Storage time of allogeneic red blood cells is associated with risk of severe postoperative infection after coronary artery bypass grafting. Eur J Cardiothorac Surg 39:329-34.

Cholette JM, Powers KS, Alfieris GM, et al. 2013. Transfusion of cell saver salvaged blood in neonates and infants undergoing open heart surgery significantly reduces RBC and coagulant product transfusions and donor exposures: results of a prospective, randomized, clinical trial. Pediatr Crit Care Med 14:137-47.

Jiang GQ, Bai DS, Chen P, et al. 2014. Modified laparoscopic splenectomy and azygoportal disconnection combined with cell salvage is feasible and might reduce the need for blood transfusion. World J Gastroenterol. 20:420-6.

Kuss O, von Salviati B, Börgermann J. 2010. Off-pump versus on-pump coronary artery bypass grafting: a systematic review and meta-analysis of propensity score analyses. Thorac Cardiovasc Surg 140:829-35.

Milne ME, Yazer MH, Waters JH, et al. 2015. Red blood cell salvage during obstetric hemorrhage. Obstet Gynecol.2015:919-23.

Ong LP, Thompson E, Sachdeva A, et al. 2016. Allogeneic blood transfusion in bilateral lung transplantation: impact on early Function and mortality. Eur J Cardiothorac Surg 49:668-74.

Saha KK, Deval M, Jagdale L, Sahani P. 2011. Off-pump coronary artery bypass grafting in a low-volume center. Heart Surg Forum 14:E349-53.

Scott AV, Nagababu E, Johnson DJ, et al. 2016. 2,3- diphosphoglycerate concentrations in autologous salvaged versus stored red blood cells and in surgical patients after transfusion. Anesth Analg 122:616-23.

Stone GW, Clayton TC, Mehran R, et al. 2012. Impact of major bleeding and blood transfusions after cardiac surgery: analysis from the Acute Catheterization and Urgent Intervention Triage strategy trial. Am Heart 
J 163:522-9.

Tan NL, Corbineau H, Phu BD, Verhoye JP. 2012. Is a cell saver necessary in off-pump coronary artery bypass surgery? Asian Cardiovasc Thorac Ann 20: 539-43.

Vassal O, Desgranges FP, Tosetti S, et al. 2016. Risk factors for intraoperative allogeneic blood transfusion during craniotomy for brain tumor removal in children. Paediatr Anaesth 26:199-206.

Vonk AB, Meesters MI, Garnier, et al. 2013. Intraoperative cell salvage is associated with reduced postoperative blood loss and transfusion requirements in cardiac surgery: a cohort study. Transfusion 53:2782-9. 